\title{
Target tissue production and axonal transport of neurotrophin-3 are reduced in streptozotocin-diabetic rats
}

\author{
P. Fernyhough, L. T. Diemel, D. R. Tomlinson \\ Department of Pharmacology, St. Bartholomew's and Royal London School of Medicine and Dentistry, Queen Mary and Westfield \\ College, University of London, London, UK
}

\begin{abstract}
Summary Neurotrophin-3 (NT-3) acts as a target-derived neurotrophic factor for large calibre sensory neurones and plays a role in the maintenance of the adult phenotype of proprioceptive and mechanoreceptive fibres. Large fibre sensory neuropathy is common in diabetes mellitus and the aim of this study was to determine whether endogenous NT-3-dependent neurotrophic support was sub-optimal in the streptozotocin-diabetic rat. NT-3 gene expression was analysed by Northern blotting and ELISA in hindlimb skeletal muscle and found to be decreased by up to $70 \%(p<0.05)$ in rats with $4-6$ weeks of diabetes compared to aged-matched controls. Treatment of other diabetic rats with insulin prevented development of deficits of both NT-3 protein and of its
\end{abstract}

mRNA. The deficits in target tissue production of NT-3 were coincident with significant decreases in its anterograde and retrograde axonal transport in sciatic nerve at 6 weeks of diabetes. The mRNA expression in lumbar dorsal root ganglia of the specific receptor for NT-3, trkC, was also down-regulated at 12 weeks of diabetes by $50 \%(p<0.05)$. The observed decreases in NT-3 target tissue production and related axonal transport suggest that large calibre sensory neurones expressing trkC may be receiving sub-optimal neurotrophic support in experimental diabetes. [Diabetologia (1998) 41: 300-306]

Keywords Neuropathy, dorsal root ganglia, neurotrophins, sciatic nerve, neurotropin, trkC.
Neurotrophin-3 (NT-3) is a member of a structurally related group of neurotrophic peptides that include nerve growth factor (NGF), brain-derived neurotrophic factor (BDNF) and neurotrophin-4/5 (NT4) and that combine to regulate the development and maintenance of the vertebrate peripheral nervous system $[1,2]$. A role for NGF in the aetiology of diabetic neuropathy was suggested following demonstration of deficient retrograde axonal transport of ${ }^{125}$ I-labelled NGF in sciatic [3] and ileal mesenteric

Received: 12 August 1997 and in revised form: 7 November 1997

Corresponding author: Dr. P. Fernyhough, Department of Pharmacology, St. Bartholomew's and Royal London School of Medicine and Dentistry, Queen Mary and Westfield College, University of London, London, E1 4NS, UK

Abbreviations: NT-3, Neurotrophin-3; NGF, nerve growth factor; DRG, dorsal root ganglia; EDL, extensor digitorus longus muscle.
[4] nerves of diabetic rats. Recent studies have established a clear relationship between deficient NGF expression in target tissues of the lower limb [5], reduced retrograde transport of endogenous NGF to the lumbar dorsal root ganglia (DRG) $[6,7]$ and reduced expression of the neuropeptides, substance $\mathrm{P}$ and calcitonin gene-related peptide (CGRP), which are neuronal targets for NGF in C-fibers $[8,9]$. These experimental observations indicate a mechanism for suppression of small calibre C-fibre activity in diabetic sensory neuropathy and clinical evidence supports such an involvement in general cases [10].

Large calibre myelinated sensory fibres undergo degeneration in human diabetic neuropathy [11]. In experimental models of diabetes fibre degeneration is not well characterised; however, large myelinated sensory fibres do undergo loss of calibre [12] and are implicated in the occurrence of tactile allodynia, a feature of abnormal $\beta$-mechanoreceptor function [13]. In the clinical situation these abnormal proper- 
ties of myelinated sensory fibres may contribute to hyperalgesia and the loss of protective sensation in the foot. While NGF may support a small proportion of these neurons [14] there is mounting evidence that NT-3 is a growth factor for large calibre sensory neurons during development [15-19]. Postnatally, and in the adult, NT-3 supports discrete populations of proprioceptive, A $\delta$ and slowly adapting mechanoreceptive sensory fibre types $[20,21]$. Most recently, application of trkC-Ig to the rat hindlimb was shown to decrease gastrocnemius nerve motor and sensory nerve conduction velocities, presumably, through sequestration of endogenous NT-3 [22]. Additionally, the degeneration of large myelinated central projections within the dorsal column observed upon peripheral axotomy of the sensory neurone was prevented by NT-3 treatment [23]. Furthermore, decreases in sensory nerve conduction velocity associated with cisplatin- and pyridoxine-induced peripheral neuropathies have been shown to be normalised upon systemic NT-3 treatment [24, 25]. There is, therefore, mounting evidence that in the adult rat the large calibre sensory neurones and, possibly motor neurones, require neurotrophic support from NT-3 for optimal performance.

Recent studies show that NT-3 mRNA was reduced in sciatic nerve and hindlimb skeletal muscle of streptozotocin-diabetic rats [26-28]. As a first step in determining the possible role of NT-3 in the aetiology of large fibre neuropathy in diabetes the aim of this study was to determine the effect of experimental diabetes on the endogenous production of NT-3 by sensory neurone target tissue and its subsequent axonal transport within the sciatic nerve. Additionally, the effect of diabetes on the expression of the specific NT-3 receptor, trkC, was analysed in the lumbar DRG.

\section{Materials and methods}

Animal protocols. Male Wistar rats (250-300 g), following an overnight fast, were made diabetic with $45-65 \mathrm{mg} / \mathrm{kg}$ i. p. streptozotocin (Sigma, St. Louis, Mo., USA). Two durations of diabetes -6 weeks and 12 weeks - were examined in detail and each contained cohorts of diabetic rats without treatment. There were also diabetic cohorts in which glycaemia was controlled by means of sustained insulin delivering implants for the final 4 week (i.e. weeks 2 to 6 or weeks 8 to 12). To this end rats were anaesthetised under halothane and two insulin implants (4 IU $\cdot$ day $^{-1} \cdot$ rat $^{-1}$; Linplants; Møllegaard Breeding Centre A/S, Skensved, Denmark) inserted subcutaneously into the back of the neck. Measurement of blood glucose concentration at regular intervals confirmed that the implants effectively attenuated hyperglycaemia (to $<10 \mathrm{mmol} / \mathrm{l}$ ) without causing the rats to become hypoglycaemic. Age-matched nondiabetic rats formed two control groups for the 6 and 12 week studies. As specifically mentioned in the Results diabetic groups of shorter duration were also included to study rates of development of some deficits.
Groups of control rats and 6 week diabetic rats with and without insulin implants were subjected to a unilateral sciatic nerve ligation. Briefly, animals were anaesthetized under halothane, the left flank was opened and the sciatic nerve cleared and a single ligature placed at the level of the sciatic notch for $6 \mathrm{~h}$.

All animals were given unrestricted access to water and food and were killed by a blow to the head and bled from the throat. A blood sample was taken and assayed for glucose assay using the GOD-PERID test kit (Boehringer Mannheim, Mannheim, Germany). Only diabetic rats with a plasma glucose level greater than $25.0 \mathrm{mmol} / \mathrm{l}$ were subsequently included in the study. All animal procedures followed strict guidelines laid down by the UK Home Office.

Isolation of total RNA and Northern blotting. Total RNA was isolated as described elsewhere [29]. Briefly, approximately $100-150 \mathrm{mg}$ of minced soleus or extensor digitorus longus (EDL) muscle, or 4 lumbar $\mathrm{L}_{4}$ and $\mathrm{L}_{5}$ DRG, were homogenized (Polytron; Kinematica, Luzern, Switzerland) in $1 \mathrm{ml}$ of a guanidine thiocyanate based homogenization solution. Total RNA was extracted twice with phenol:chloroform and quantified by the optical density reading at $260 \mathrm{~nm}$ and the purity estimated by the $260 / 280 \mathrm{~nm}$ ratio. The total RNA was subjected to Northern blotting. Equivalent amounts of total RNA (10-25 $\mu \mathrm{g}$ ) were size fractionated in a $1.2 \%$ agarose/ formaldehyde gel [30]. Ethidium bromide staining was used to determine the position of the $18 \mathrm{~S}$ and $28 \mathrm{~S}$ rRNA subunits and to confirm that equivalent amounts of undegraded RNA had been loaded. The fractionated RNA was transferred to Nytran-N nitrocellulose (Schleicher and Schuell, Dassel, Germany) using a posiblot transfer system (Stratagene, La Jolla, Calif., USA) as described previously [31] and fixed to the membrane by cross-linking under ultra-violet light (Stratalinker, Stratagene).

Detection of specific $m R N A$ species. The cDNA probe for $\beta$-actin was purchased from Clontech (Palo Alto, CA., USA), consisted of a $2 \mathrm{~kb}$ insert, and is described elsewhere [32]. The rat NT-3 and trkC probes were given by Dr. G. Yancopoulos (Regeneron, Tarrytown, NY., USA) [33, 34]. The trkC probe was a 800 bp cDNA coding for the kinase domain and specific for the full-length receptor transcript. The detection of $28 \mathrm{~S}$ rRNA has been described previously [35]. Full length singlestranded antisense ${ }^{32} \mathrm{P}$-labelled DNA probes were generated from the NT-3 and trkC cDNAs using asymmetric polymerase chain reaction (PCR). Other probes were random primer ${ }^{32} \mathrm{P}$ labelled using a kit (Promega, Madison, Wis., USA). Hybridization to nitrocellulose filters proceeded for $16-18 \mathrm{~h}$ at $65^{\circ} \mathrm{C}$, the solution consisting of $0.5 \mathrm{mmol} / 1 \mathrm{Na}_{2} \mathrm{HPO}_{4} \mathrm{pH} 7.0,7 \%$ sodium dodecyl sulfate, $1 \%$ bovine serum albumin (fraction $\mathrm{V}$ ), $1.0 \mathrm{mmol} / 1 \mathrm{EDTA}$, and $0.1 \mathrm{mg} / \mathrm{ml}$ salmon sperm DNA [36]. The blots were washed to a final concentration of $1 \times$ SSC $(75.0 \mathrm{mmol} / \mathrm{l} \mathrm{NaCl}, 7.5 \mathrm{mmol} / \mathrm{l}$ sodium citrate, $5.0 \mathrm{mmol} / \mathrm{l}$ $\mathrm{Na}_{2} \mathrm{HP}_{4}, 0.015 \%$ pyrophosphate, and $0.025 \%$ sodium dodecyl sulphate, $\mathrm{pH} 7.0$ ), and down to $0.5 \times \mathrm{SSC}$ for $\beta$-actin. All washes were performed at $68^{\circ} \mathrm{C}$. Blots were probed sequentially, in between probings the blots were stripped using a solution of $1 \%$ sodium dodecyl sulphate in $0.01 \times \mathrm{SSC}$ at $95^{\circ} \mathrm{C}$.

Autoradiograms were prepared on Fuji X-ray film using a single enhancing screen at $-70^{\circ} \mathrm{C}$ (laid down for up to 3 weeks). Measurement of the level of hybridization detected by the X-ray film was made using an image analyser (AI Cambridge Herts, UK). The data for NT-3 mRNA levels are presented relative to $B$-actin mRNA and for trkC transcripts relative to $28 \mathrm{~S}$ rRNA. All data were then normalized to each mRNA level in tissues from control rats. 


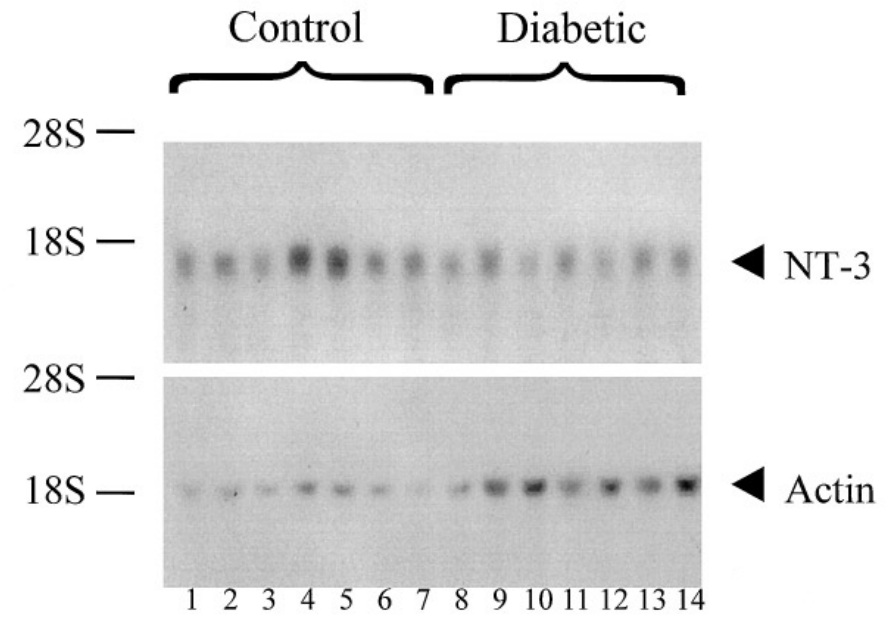

Fig. 1. Effect of 12 week diabetes on NT-3 mRNA levels in soleus muscle. Autoradiograms derived from a Northern blot probed sequentially for NT-3 and $\beta$-actin mRNAs. Positions of the $18 \mathrm{~S}$ and $28 \mathrm{~S}$ rRNA bands are indicated. Lanes $1-7$, control; lanes 8-14, diabetic

NT-3 ELISA. Nerve (10-40 mg wet weight) and muscle (100 mg wet weight) were frozen on dry ice and then homogenized in $0.5-1.0 \mathrm{ml}$ of $50 \mathrm{mmol} / \mathrm{l}$ Tris. $\mathrm{HCl}, \mathrm{pH} 7.4,600 \mathrm{mmol} / \mathrm{l}$ $\mathrm{NaCl}, 0.2 \%$ Triton X-100, $1 \%$ BSA (fraction V), 200 Kallikrein inhibitor units $/ \mathrm{ml}$ aprotinin, $0.1 \mathrm{mmol} / \mathrm{l}$ benzathonium chloride, $1.0 \mathrm{mmol} / \mathrm{l}$ benzamidine and $0.1 \mathrm{mmol} / \mathrm{l}$ phenylmethylsulphonyl fluoride (PMSF). Homogenates were centrifuged at $10000 \times g$ at $4{ }^{\circ} \mathrm{C}$ for $10 \mathrm{~min}$ and supernatants applied in triplicate to a specific ELISA for NT-3. The ELISA utilised a highly specific monoclonal antibody against human recombinant NT-3 developed at Regeneron Pharmaceuticals, Tarrytown, N. Y., USA; one antibody was used for capture and the other was biotinylated for reporting. These antibodies only showed cross-reactivity with any other neurotrophin at concentrations $1000 \times$ higher than the top concentration used for the NT-3 standard curve.

Statistical analysis. Where appropriate data were subjected to one-way analysis of variance (one-way ANOVA) using SPSS for Windows. Where the $F$ ratio gave $p<0.05$, comparisons between individual group means were made by Duncan's multiple range test at significance levels of $p=0.05$. Levene's test was used to examine the data for homogeneity of variance, accepting $p>0.05$. Other comparisons were made with Student's $t$-test (unpaired).

\section{Results}

Effect of diabetes on plasma glucose and body weight. Table 1 shows the plasma glucose and body weight data for the animal groups studied. As early as 2 weeks of diabetes there was a loss of body mass of approximately $18 \%$ compared with aged-matched control animals, with progression to 12 weeks of diabetes this loss of body weight increased to $43 \%$.

Effect of diabetes on expression of NT-3 in hindlimb skeletal muscle. Figure 1 and Table 2 show that
Table 1. Body weight and plasma glucose data

\begin{tabular}{llll}
\hline & Body weight $(\mathrm{g})$ & $\begin{array}{l}\text { Plasma glucose } \\
(\mathrm{mmol} / \mathrm{l})\end{array}$ \\
\hline 2 week & Control & $448 \pm 34^{\mathrm{a}}$ & $11.4 \pm 1.8^{\mathrm{a}}$ \\
& Diabetic & $333 \pm 25$ & $39.3 \pm 8.5$ \\
4 week & Diabetic & $343 \pm 9$ & $40.3 \pm 6$ \\
6 week & Control & $474 \pm 16$ & $11.4 \pm 1.4$ \\
& Diabetic & $315 \pm 16^{\mathrm{b}}$ & $44.7 \pm 4.1^{\mathrm{b}}$ \\
& Diabetic + Insulin & $491 \pm 25$ & $10.8 \pm 2$ \\
12 week & Control & $562 \pm 52$ & $11.5 \pm 2.5$ \\
& Diabetic & $320 \pm 25^{\mathrm{b}}$ & $50.7 \pm 6.3^{\mathrm{b}}$ \\
& Diabetic + Insulin & $455 \pm 15$ & $10.6 \pm 7.5$ \\
\hline
\end{tabular}

Values are means \pm SD $(n=7-9)$. Starting body weights were $320-350 \mathrm{~g}$ for all groups. The data for experiments 1 and 2 at 12 weeks of diabetes were essentially the same. ${ }^{a} p<0.001$ for control vs diabetic (unpaired $t$-test) $;{ }^{\mathrm{b}} p<0.001$ for diabetic vs other groups (one way ANOVA)

Table 2. Effect of duration of diabetes on neurotrophin-3 mRNA levels in soleus muscle

\begin{tabular}{llll}
\hline & $\begin{array}{l}\text { 6 weeks } \\
\text { diabetes }\end{array}$ & \multicolumn{2}{l}{ 12 weeks diabetes } \\
\cline { 3 - 4 } & Experiment 1 & Experiment 2 \\
\hline$n$ & 6 & 7 & $4-5$ \\
Control & $1.0 \pm 0.39^{\mathrm{a}}$ & $1.0 \pm 0.42^{\mathrm{a}}$ & $1.0 \pm 0.14$ \\
$\begin{array}{l}\text { Diabetic } \\
\text { Diabetic }+\end{array}$ & $0.31 \pm 0.11$ & $0.29 \pm 0.15$ & $0.44 \pm 0.18^{\mathrm{b}}$ \\
Insulin & ND & ND & $0.77 \pm 0.18$ \\
\hline
\end{tabular}

Values are means \pm SD. Data have been expressed relative to actin mRNA levels and normalised to control. The data were essentially the same when expressed per total RNA. Experiment 1 was performed without an insulin-treated group and then repeated (Experiment 2), with insulin treatment when the NT-3 mRNA deficit was seen. ${ }^{a} p<0.05$ for control vs diabetic; ${ }^{\mathrm{b}} p<0.05$ for diabetic vs other groups (one way ANOVA). ND = not determined

mRNA levels for NT-3 were reduced by $70 \%$ at 6 and 12 weeks of diabetes (Experiment 1). A second experiment was then performed in which diabetic rats were given insulin implants (final 4 weeks of 12 weeks diabetes) and under these conditions the deficit in NT-3 mRNA, which was $56 \%$, was significantly reversed $(p<0.05$; one way ANOVA). Because NT-3 mRNA levels were decreased by 6 weeks of diabetes a follow-up study was performed at 2, 4 and 6 weeks of diabetes where NT-3 protein levels were quantified in soleus and EDL muscles. There was no decrease in NT-3 protein levels at 2 weeks of diabetes in either muscle (Table 3). At 4 weeks of diabetes the levels of NT-3 protein were below the detection limit ( $<4.0 \mathrm{pg} / \mathrm{mg}$; data not shown). At 6 weeks of diabetes the amount of NT-3 remained below the detection limit and insulin therapy for the final 4 weeks increased NT-3 protein to detectable levels (Table 3).

Northern blots were also prepared from total RNA isolated from hindpaw foot skin of control and 
Table 3. Effect of duration of diabetes on neurotrophin-3 protein levels in soleus and EDL muscles

\begin{tabular}{llllll}
\hline & Soleus & & & EDL \\
\cline { 2 - 3 } \cline { 5 - 6 } & 2 weeks & 6 weeks & & 2 weeks & 6 weeks \\
\hline$n$ & $7-8$ & $7-8$ & $7-9$ & 8 \\
Control & $50.7 \pm 25.0$ & $95.7 \pm 34.0$ & & $49.1 \pm 31.0$ & $93.1 \pm 21.3$ \\
Diabetic & $47.0 \pm 32.3$ & $<4.0$ & $39.4 \pm 35.2$ & $<4.0$ \\
$\begin{array}{l}\text { Diabetic }+ \\
\text { Insulin }\end{array}$ & N.D. & $62.8 \pm 17.9$ & N.D. & $51.3 \pm 33.3$ \\
\hline
\end{tabular}

Values are means \pm SD. Data are in $\mathrm{pg} / \mathrm{mg}$ wet weight of muscle. At 4 weeks of diabetes the level of NT-3 protein was $<4.0 \mathrm{pg} / \mathrm{mg}$ for soleus and EDL. N.D. = not determined; $<4.0=$ below the $4 \mathrm{pg} / \mathrm{mg}$ detection limit of the ELISA

Table 4. Anterograde and retrograde axonal transport of neurotrophin-3 in sciatic nerve of normal and 6 week diabetic rats

\begin{tabular}{llll}
\hline & $\begin{array}{l}\text { Contralateral } \\
\text { nerve }\end{array}$ & Proximal nerve & Distal nerve \\
\hline$n$ & $5-6$ & $5-6$ & $5-6$ \\
Control & $69.2 \pm 40.1$ & $460.8 \pm 141.6^{\text {a }}$ & $470.1 \pm 133.2^{\text {a }}$ \\
Diabetic & $<40.0$ & $142.7 \pm 56.2$ & $138.7 \pm 110.6$ \\
\hline
\end{tabular}

Values are means \pm SD. Data are in $\mathrm{pg} / \mathrm{cm}$ of nerve. ${ }^{\mathrm{a}} p<0.001$ control vs diabetic. $<40.0=$ below detection limit of $40.0 \mathrm{pg} /$ $\mathrm{cm}$ of ELISA

Table 5. Effect of diabetes on trkC mRNA levels in lumbar DRG

\begin{tabular}{lll}
\hline & trkC mRNA levels & \\
\cline { 2 - 3 } & 6 weeks & 12 weeks \\
\hline Control & $1.0 \pm 0.5$ & $1.0 \pm 0.53^{\mathrm{a}}$ \\
Diabetic & $1.36 \pm 0.7$ & $0.5 \pm 0.28$ \\
\hline
\end{tabular}

Values are means \pm SD $(n=6-7)$. Data have been expressed relative to the level of $28 \mathrm{~S}$ rRNA and normalised to control. The data essentially were the same when expressed per total RNA. ${ }^{a} p<0.05$ for control vs diabetic

12 week diabetic rats. No change in the levels of NT3 mRNA was observed. NT-3 protein levels in foot skin were not determined due to the inability to homogenize foot skin satisfactorily.

Effect of diabetes on axonal transport of NT-3. Control and 6 weeks diabetic rats were subjected to unilateral sciatic nerve ligatures of $6 \mathrm{~h}$ duration in order to measure anterograde (proximal nerve segment) and retrograde (distal nerve segment) axonal transport of NT-3. Table 4 shows that in control sciatic nerve axonal transport of NT-3 proceeded in both anterograde and retrograde directions. Rats with 6 weeks diabetes exhibited significantly reduced levels of NT-3 protein axonal transport in both directions. Additionally, the intact contralateral nerve data (basal level) showed that in 6 week diabetic rats the amount of NT-3 protein was below the detection limit of the ELISA.

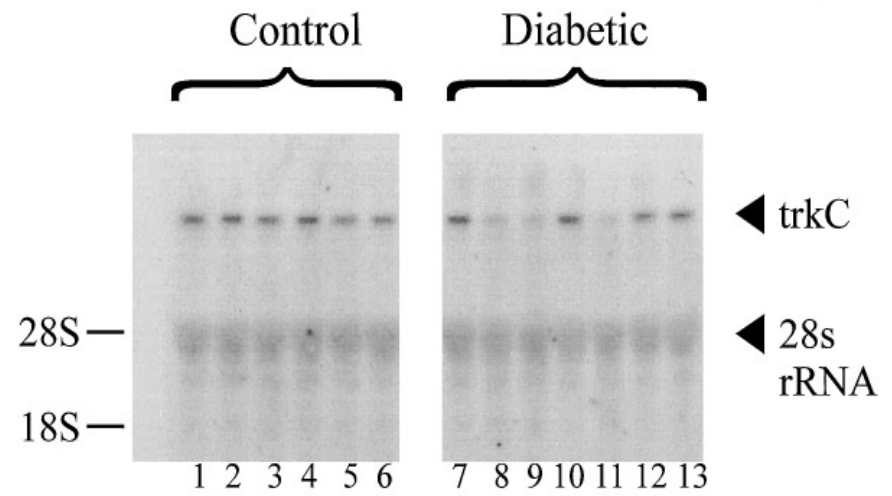

Fig. 2. Effect of 12 weeks diabetes on trkC mRNA levels in lumbar DRG. Autoradiograms derived from a Northern blot probed simultaneously for trkC and $28 \mathrm{~S}$ rRNA. Lanes 1-6, control; lanes 7-13, diabetic

Effect of diabetes on trkC mRNA expression in lumbar DRG. Table 5 shows that trkC mRNA levels were decreased by $50 \%(p<0.05)$ in $\mathrm{L}_{4}$ and $\mathrm{L}_{5} \mathrm{DRG}$ of rats with diabetes of 12 weeks duration. At 6 weeks of diabetes there was no significant difference in trkC mRNA levels within the DRG of control and diabetic rats.

\section{Discussion}

This study shows for the first time that gene expression of NT-3 in hindlimb skeletal muscle is decreased in streptozotocin-diabetes and corresponds with decreased axonal transport of the protein. Previous studies have shown reduced mRNA expression in soleus muscle and gastrocnemius muscle [26, 27], but the inclusion of NT-3 protein measurements considerably strengthens the case for reduced NT-3-dependent neurotrophic support in diabetes.

Decreased mRNA expression for NT-3 in soleus muscle of diabetic rats was significantly reduced by 6 weeks of diabetes and this reduction was maintained for up to 12 weeks (Fig. 1 and Table 2). Similar reductions in NT-3 mRNA were also seen at 8 weeks of diabetes (data not shown). The measurement of NT-3 protein revealed that the first deficit in NT-3 expression was apparent at 4 weeks and still present at 6 weeks of diabetes (Table 3 - the NT-3 protein levels in soleus and EDL muscles of the 4 week diabetic group were below the detection limit of the ELISA; data not shown). At 2 weeks of diabetes there was no change in the NT-3 protein levels in soleus and EDL muscles (Table 3). Clearly, hyperglycaemia may underlie the reduction in expression of NT-3 in hindlimb skeletal muscle, alternatively lack of insulin and possibly muscle wasting may be important these possibilities will require investigation.

The source of the NT-3 protein in hindlimb muscle is not absolutely clear. Studies during development 
and in the adult rat show that the intrafusal muscle fibres of the muscle spindle express NT-3 mRNA [20]. Certainly, a proportion of the NT-3 expression measured in this study presumably originates from the muscle spindle, which is a target for proprioceptive sensory neurons that are known to express trk $\mathrm{C}$, the specific tyrosine kinase receptor for NT-3 [15, 16]. However, the level of expression in muscle as a whole is high and it seems unlikely that spindles are the sole source. Another possibility is a Schwann cell-derived production of NT-3 by distal nerve endings within the muscle, and in fact, there is expression in sciatic nerve, which is down-regulated at 12 weeks of diabetes $[28,37]$. Further information on the source of NT-3 may come from our novel demonstration of anterograde transport of NT-3 within the sciatic nerve. The function of such a transport mechanism is unknown, but motor and/or sensory neurone-mediated release of this transported NT-3 may contribute to the NT-3 protein levels measured in muscle (Table 4 ). The decreased expression of NT-3 in muscle at 6 weeks of diabetes corresponded with reduced retrograde axonal transport of the protein (Table 4). This fits the pattern of reduced target-derived neurotrophic support leading to transfer of the deficit to the innervating neurones via deficient retrograde transport.

Studies on hindpaw foot skin showed no change in NT-3 mRNA expression at 12 weeks of diabetes; however, we were unable to measure protein levels in this tissue. This result suggests that at this time point of diabetes there is no significant down-regulation of NT-3-dependent neurotrophic support of trkC positive neurones inervating foot skin. Studies show that the trkC positive neurones inervating skin include mechanoreceptive and A $\delta$ sub-types [21].

The observation of anterograde axonal transport of NT-3, as mentioned above, was both novel and interesting, particularly in view of the deficit thereof seen in diabetic rats (Table 4). The origin of the anterogradely transported NT-3 may be only surmised, but sensory and, especially, motor neurone cell bodies are the likely candidates $[19,38]$. A possibility that cannot be discounted is that the transported NT-3 is recycled within the sciatic nerve. Another important consideration is that the source of NT-3 measured as accumulations at the ligatures derives from ligature-induced local synthesis by Schwann cells and/or fibroblasts of the sciatic nerve, as is observed for NGF [39]. In fact, sciatic nerve induces a significant reduction in local synthesis of NT-3 mRNA levels at $6 \mathrm{~h}$ and this effect is maintained for up to 1 week [40]. These results suggest that the accumulation of NT-3 measured proximal and distal to the ligature were, indeed, derived from axonal transport. The level of accumulation of NT-3 protein observed at $6 \mathrm{~h}$ proximal and distal to the ligature was approximately 6.5-times greater than the level of NT-3 protein found per $\mathrm{cm}$ of intact nerve. Such an observation suggests a rate of axonal transport of less than $1 \mathrm{~cm} / \mathrm{h}$, this is indicative of fast axonal transport and mimics the properties of axonal transport of NGF in sciatic nerve $[6$, 41].

Taken together, our data show clearly that a deficit in NT-3-dependent neurotrophic support is present in streptozotocin-diabetic rats. It is also possible that the sensitivity of NT-3 dependent sensory neurones is affected in diabetes and may contribute to the reduced level of retrograde axonal transport of NT-3; hence, we measured the levels of mRNA for the trkC receptor. Table 5 shows that trkC transcripts in lumbar DRG were reduced by $50 \%$ in 12 week diabetic rats, with no difference observed at 6 weeks of diabetes. These results suggest that NT-3-dependent sensory neurones may well have a reduced capacity to bind and internalise NT-3, although caution must be employed until studies on the expression of the trkC receptor protein are undertaken. Previous studies show that mRNA expression of $\mathrm{p} 75^{\mathrm{LNTR}}$ in DRG is significantly reduced by 9 weeks of diabetes [42] and this receptor has been shown to bind NT-3 with high affinity in embryonic sympathetic neurones [43]. Therefore, reduced availability of trkC and $\mathrm{p} 75^{\mathrm{LNTR}}$ receptors may combine to contribute to reduced sensitivity to peripherally derived NT-3.

The deficit in NT-3 expression by hindlimb muscle is observed as early as 4 weeks of diabetes, significantly preceding changes in expression of trkC within the DRG. At 6 weeks of diabetes expression of trkC and $\mathrm{p} 75^{\mathrm{LNTR}}$ transcripts in DRG are unaffected by diabetes (p75 LNTR data not shown). Assuming the mRNA expression relates in some way to receptor protein levels it, therefore, is most likely that the reduced level of retrograde axonal transport of NT-3 observed at 6 weeks of diabetes is the result of a production deficit for NT-3 in the target muscle and not due to a reduced sensitivity to NT-3 derived from decreased receptor expression within the DRG.

Deficits in motor and sensory nerve conduction velocity develop very early in experimental diabetes, in most cases prior to 4 weeks post-onset. Tactile allodynia, another indicator of abnormal large sensory myelinated fibre activity, also develops rapidly within the second to third week in the streptozotocin-diabetic rat [13]. In the study presented here reductions in NT-3-dependent neurotrophic support were not clearly defined until 4 weeks of diabetes. However, it is likely that down-regulation of NT-3 transcript expression in muscle occurs from 2 weeks onwards. Therefore, it seems possible that a deficient supply of endogenous NT-3 is pivotal in the aetiology of these parameters of peripheral neuropathy. Furthermore, it is possible that a long-term diminution of NT-3-dependent neurotrophic support may be involved in the structural abnormalities observed in myelinated sensory fibres that can occur after longer 
periods of diabetes in animal models [12]. Therefore, treatment with exogenous NT-3 may successfully reverse abnormalities in motor and sensory nerve conduction velocity and mechanoreceptor function and these studies are underway.

In summary, the results presented show that NT-3dependent neurotrophic support is sub-optimal in streptozotocin-diabetic rats. Reduced target tissue production of NT-3 results in deficits in axonal transport of NT-3 and may contribute to the development of large fibre neuropathy in diabetes.

Acknowledgements. This work was funded by the Wellcome Trust (P.F. and D.R.T) and the Medical Research Council (to D. R.T. for L. T.D.). We thank Dr. Ann Acheson and the Biological Assay Development Group at Regeneron Pharmaceuticals for setting up and performing the NT-3 ELISA. We also thank Drs. Ron Lindsay and George Yancopoulos and colleagues at Regeneron Pharmaceuticals for the gift of the cDNA clones for rat NT-3 and trkC.

\section{References}

1. Thoenen H (1991) The changing scene of neurotrophic factors. Trends Neurosci 14: 165-170

2. Barde Y-A (1994) Neurotrophic factors: An evolutionary perspective. J Neurobiol 25:1329-1333

3. Jakobsen J, Brimijoin S, Skau K, Sidenius P, Wells D (1981) Retrograde axonal transport of transmitter enzymes, fucose-labeled protein, and nerve growth factor in streptozotocin-diabetic rats. Diabetes 30:797-803

4. Schmidt RE, Grabau GG, Yip HK (1986) Retrograde axonal transport of $\left[{ }^{125} \mathrm{I}\right]$ nerve growth factor in ileal mesenteric nerves in vitro: effect of streptozotocin diabetes. Brain Res 378:325-336

5. Fernyhough P, Diemel LT, Brewster WJ, Tomlinson DR (1994) Deficits in sciatic nerve neuropeptide content coincide with a reduction in target tissue nerve growth factor mRNA in streptozotocin-diabetic rats; effects of insulin treatment. Neuroscience 62:337-344

6. Fernyhough P, Diemel LT, Hardy J, Brewster WJ, Mohiuddin L, Tomlinson DR (1995) Human recombinant nerve growth factor replaces deficient neurotrophic support in the diabetic rat. Eur J Neurosci 7:1107-1110

7. Hellweg R, Hartung H-D (1990) Endogenous levels of nerve growth factor (NGF) are altered in experimental diabetes mellitus: a possible role for NGF in the pathogenesis of diabetic neuropathy. J Neurosci Res 26:258-267

8. Diemel LT, Brewster WJ, Fernyhough P, Tomlinson DR (1994) Expression of neuropeptides in experimental diabetes; effects of treatment with nerve growth factor or brainderived neurotrophic factor. Mol Brain Res 21:171-175

9. Apfel SC, Arezzo JC, Brownlee M, Federoff H, Kessler JA (1994) Nerve growth factor administration protects against experimental diabetic sensory neuropathy. Brain Res 634:7-12

10. Aronin N, Leeman SE, Clements RS, Jr. (1987) Diminished flare response in neuropathic diabetic patients. Comparison of effects of substance $\mathrm{P}$, histamine, and capsaicin. Diabetes 36:1139-1143

11. Thomas PK, Tomlinson DR (1992) Diabetic and hypoglycaemic neuropathy. In: Peripheral neuropathy. Dyck PJ, Thomas PK, Griffin JW, Low PA, Poduslo JF (eds) W.B.
Saunders Co. Philadelphia, London, Toronto, Montreal, Sydney, Tokyo, pp 1219-1250

12. Yagihashi S, Kamijo M, Watanabe K (1990) Reduced myelinated fiber size correlates with loss of axonal neurofilaments in peripheral nerve of chronically streptozotocin diabetic rats. Am J Pathol 136:1365-1373

13. Courteix C, Eschalier A, Lavarenne J (1993) Streptozocininduced diabetic rats: behavioural evidence for a model of chronic pain. Pain 53:81-88

14. Verge VMK, Tetzlaff W, Bisby MA, Richardson PM (1990) Influence of nerve growth factor on neurofilament gene expression in mature primary sensory neurons. J Neurosci 10:2018-2025

15. Klein R, Silos-Santiago I, Smeyne RJ et al. (1994) Disruption of the neurotrophin-3 receptor gene trkC eliminates muscle afferents and results in abnormal movements. Nature 368:249-251

16. Ernfors P, Lee K-F, Kucera J, Jaenisch R (1994) Lack of neurotrophin-3 leads to deficiencies in the peripheral nervous system and loss of limb proprioceptive afferents. Cell 77:503-512

17. Tessarollo L, Vogel KS, Palko ME, Reid SW, Parada LF (1994) Targeted mutation in the neurotrophin-3 gene results in loss of muscle sensory neurons. Proc Natl Acad Sci USA 91:11844-11848

18. Fariñas I, Jones KR, Backus C, Wang X-Y, Reichardt LF (1994) Severe sensory and sympathetic deficits in mice lacking neurotrophin-3. Nature 369:658-661

19. Schecterson LC, Bothwell M (1992) Novel roles for neurotrophins are suggested by BDNF and NT-3 mRNA expression in developing neurons. Neuron 9:449-463

20. Copray JCVM, Brouwer N (1994) Selective expression of neurotrophin-3 messenger RNA in muscle spindles of the rat. Neuroscience 63:1125-1135

21. Airaksinen MS, Koltzenburg M, Lewin GR et al. (1996) Specific subtypes of cutaneous mechanoreceptors require neurotrophin-3 following peripheral target innervation. Neuron 16:287-295

22. Munson JB, Shelton DL, McMahon SB (1997) Adult mammalian sensory and motor neurons: roles of endogenous neurotrophins and rescue by exogenous neurotrophins after axotomy. J Neurosci 17:470-476

23. Ohara S, Tantuwaya V, DiStefano PS, Schmidt RE (1995) Exogenous NT-3 mitigates the transganglionic neuropeptide Y response to sciatic nerve injury. Brain Res 699:143148

24. Gao W-Q, Dybdal N, Shinsky N et al. (1995) Neurotrophin-3 reverses experimental cisplatin-induced peripheral sensory neuropathy. Ann Neurol 38:30-37

25. Helgren ME, Cliffer KD, Torrento K et al. (1997) Neurotrophin-3 administration attenuates deficits of pyridoxineinduced large-fiber sensory neuropathy. $\mathbf{J}$ Neurosci $17: 372-382$

26. Tomlinson DR, Fernyhough P, Diemel LT (1996) Neurotrophins and peripheral neuropathy. Phil Trans R Soc Lond B 351:455-462

27. Ihara C, Shimatsu A, Mizuta H, Murabe H, Nakamura Y, Nakao K (1996) Decreased neurotrophin-3 expression in skeletal muscles of streptozotocin-induced diabetic rats. Neuropeptides 30:309-312

28. Rodríguez-Pena A, Botana M, González M, Requejo F (1995) Expression of neurotrophins and their receptors in sciatic nerve of experimentally diabetic rats. Neurosci Lett 200:37-40

29. Chomczynski P, Sacchi N (1987) Single-step method of RNA isolation by acid guanidinium thiocyanate-phenolchloroform extraction. Anal Biochem 162:156-159 
30. Lehrach H, Diamond D, Wozney JM, Boedtker H (1977) Ribonucleic acid molecular weight determination by gel electrophoresis under denaturing conditions, a critical reexamination. Biochemistry 16:4743-4751

31. Thomas PS (1980) Hybridization of denatured RNA and small DNA fragments transferred to nitrocellulose. Proc Natl Acad Sci USA 77:5201-5205

32. Gunning P, Ponte P, Okayama H, Engel J, Blau H, Kedes L (1983) Isolation and characterization of full-length cDNA clones for human a-, b-, and gamma-actin mRNAs: skeletal but not cytoplasmic actins have an amino-terminal cysteine that is subsequently removed. Mol Cell Biol 3:787-795

33. Maisonpierre PC, Le-Beau MM, Espinosa R et al. (1991) Human and rat brain-derived neurotrophic factor and neurotrophin-3: gene structures, distributions, and chromosomal localizations. Genomics 10:558-568

34. Valenzuela DM, Maisonpierre PC, Glass DJ et al. (1993) Alternative forms of rat TrkC with different functional capabilities. Neuron 10:963-974

35. Garrett NE, Kidd BL, Cruwys SC, Tomlinson DR (1996) Effect of streptozotocin-diabetes on knee joint inflammation-induced changes in substance $\mathrm{P}$ and nerve growth factor in the rat. Mol Brain Res 42:272-278

36. Mahmoudi M, Lin VK (1989) Comparison of two different hybridisation systems in northern transfer analysis. BioTechniques 7:331-334
37. Maisonpierre PC, Belluscio L, Squinto S et al. (1990) Neurotrophin-3: a neurotrophic factor related to $\mathrm{NGF}$ and BDNF. Science 247:1446-1451

38. Ernfors P, Persson H (1991) Developmentally regulated expression of HDNF/NT-3 mRNA in rat spinal cord motoneurons and expression of BDNF mRNA in embryonic dorsal root ganglion. Eur J Neurosci 3:953-961

39. Heumann R, Korsching S, Bandtlow CE, Thoenen $\mathrm{H}$ (1987) Changes of nerve growth factor synthesis in nonneuronal cells in response to sciatic nerve transection. $\mathbf{J}$ Cell Biol 104:1623-1631

40. Funakoshi H, Frisen J, Barbany G et al. (1993) Differential expression of mRNAs for neurotrophins and their receptors after axotomy of the sciatic nerve. J Cell Biol 123:455-465

41. Korsching S, Thoenen H (1983) Quantitative demonstration of retrograde axonal transport of endogenous nerve growth factor. Neurosci Lett 39:1-4

42. Maeda K, Fernyhough P, Tomlinson DR (1996) Regenerating sensory neurones of diabetic rats express reduced levels of mRNA for GAP-43, gamma-preprotachykinin and the nerve growth factor receptors, trkA and $\mathrm{p} 75^{\mathrm{NGFR}}$. Mol Brain Res 37:166-174

43. Dechant G, Tsoulfas P, Parada LF, Barde YA (1997) The neurotrophin receptor $\mathrm{p} 75$ binds neurotrophin-3 on sympathetic neurons with high affinity and specificity. J Neurosci 17:5281-5287 